\title{
Developmental genetics of the COPD lung
}

\author{
Kelly Probert ${ }^{\dagger}$, Suzanne Miller ${ }^{*}$, Abdul Kader Kheirallah and lan P. Hall
}

\begin{abstract}
Chronic Obstructive Pulmonary Disease (COPD) is a debilitating disease of the lung which results in irreversible airflow obstruction and is currently the third leading cause of death worldwide. Genetic and environmental factors contributing to COPD are presently under investigation. As lung function measures cluster within families, we now know that lung function is partly inherited. Thus, identifying genes involved in determining lung function at the population level and in determining the risk of development of COPD is important. A thorough understanding of the mechanisms underlying maintenance of lung function and knowledge of how these are altered in lung disease could ultimately lead to targeted therapeutic approaches. This is of potential value in COPD because current treatments are designed to reduce symptoms but do not modify disease progression. Here, we review the genes identified from both meta-analyses of genome-wide association (GWA) studies of lung function in large populations and case control GWA studies in COPD. We hypothesise that mechanisms involved in the early development of the lungs may vary/alter and predispose to COPD later in life. We discuss the genes and pathways involved in normal lung development and ascertain whether they overlap with key genes identified from GWA studies. Epigenetic factors may also play an important role in lung function, development and disease. Furthermore, we discuss our findings on the functional characterisation of HTR4 and genes within the 4q24 locus associated with both lung function and COPD. Lastly, we consider new genetic techniques and models to study candidate genes identified by the approaches discussed.
\end{abstract}

Keywords: COPD, Lung development, Lung function, Genetics, Heritability, Environment, FEV $1, \mathrm{FEV}_{1} / \mathrm{FVC}$, Developmental signalling pathways

\section{Introduction}

Diseases which cause a decline in lung function remain a huge burden to human society and the economy. One such disease, Chronic Obstructive Pulmonary Disease (COPD) is a heterogeneous and debilitating condition characterised by the development of irreversible airflow obstruction. The development of COPD has a strong environmental basis, with cigarette smoking and exposure to poor air quality being key risk factors. Unlike some common chronic diseases, the incidence of COPD has not declined in recent years, in fact there continues to be increasing prevalence, morbidity and mortality rates for COPD globally. According to the World Health Organisation, 64 million people worldwide have COPD and $>3$ million people die each year of the disease [1]. Within the UK alone it is estimated that 3 million

\footnotetext{
* Correspondence: suzanne.miller@nottingham.ac.uk

${ }^{\dagger}$ Equal contributors

Division of Respiratory Medicine, Queen's Medical Centre, University of Nottingham, Nottingham NG7 2UH, UK
}

people have COPD and it accounts for 30,000 deaths each year [2]. Critically, COPD is now the third leading cause of death worldwide, Fig. 1 [3].

In general, COPD is a progressive condition, leading to airway remodelling, inflammation and narrowing of the small airways and/ or alveolar destruction (emphysema), with symptoms generally becoming evident later in life [4]. Although the introduction of smoking bans may help to lower the incidence of COPD in some countries, not all patients with COPD are smokers [5]. It is also important to note that COPD can be caused by biomass exposure. However, in addition to environmental exposures, around $40 \%$ of variability in lung function is estimated to be heritable [6-9]. There are a range of therapeutic agents available for treatment of COPD, including short and long acting $\beta 2$ agonists, anti-muscarinic agents, inhaled and oral steroids and phosphodiesterase inhibitors: however, whilst these drugs can improve symptoms in some patients none of them have been show to alter the progression of underlying disease. 


\begin{tabular}{|c|c|c|c|c|}
\hline \multicolumn{2}{|r|}{1990} & \multicolumn{3}{|c|}{2010} \\
\hline $\begin{array}{l}\text { Mean Rank } \\
\text { (95\% UI) }\end{array}$ & Disorder & Disorder & $\begin{array}{l}\text { Mean Rank } \\
\text { (95\% UI) }\end{array}$ & $\%$ change ( $95 \%$ UI) \\
\hline $1.0(1$ to 2$)$ & 1 Ischaemic heart disease & 1 Ischaemic heart disease & $1.0(1$ to 1$)$ & 35 (29 to 39 ) \\
\hline $2.0(1$ to 2$)$ & 2 Stroke & 2 Stroke & $2.0(2$ to 2$)$ & 26 (14 to 32$)$ \\
\hline $3.0(3$ to 4$)$ & 3 Lower respiratory infections & 3 COPD & $3.4(3$ to 4$)$ & $-7(-12$ to 0$)$ \\
\hline 4.0 (3 to 4$)$ & 4 COPD & 4 Lower respiratory infections & $3.6(3$ to 4$)$ & $-18(-24$ to -11$)$ \\
\hline $5.0(5$ to 5$)$ & 5 Diarrhoea & 5 Lung cancer & $5.8(5$ to 10$)$ & 48 (24 to 61$)$ \\
\hline $6.1(6$ to 7$)$ & 6 Tuberculosis & 6 HIV/AIDS & $6.4(5$ to 8$)$ & 396 (323 to 465$)$ \\
\hline 7.3 (7 to 9$)$ & 7 Preterm birth complications & 7 Diarrhoea & 6.7 (5 to 9$)$ & $-42(-49$ to -35$)$ \\
\hline $8.6(7$ to 12$)$ & 8 Lung cancer & 8 Road Injury & $8.4(5$ to 11$)$ & 47 (18 to 86$)$ \\
\hline 9.4 (7 to 13$)$ & 9 Malaria & 9 Diabetes & $9.0(7$ to 11$)$ & 93 (68 to 102$)$ \\
\hline $10.4(8$ to 14$)$ & 10 Road Injury & 10 Tuberculosis & 10.1 (8 to 13$)$ & $-18(-35$ to -3$)$ \\
\hline $\begin{array}{l}\text { Communic } \\
\square \text { Non-comm } \\
\square \text { Injuries }\end{array}$ & $\begin{array}{l}\text { ble, maternal, neonatal, and nutr } \\
\text { nicable diseases }\end{array}$ & al disorders & & \\
\hline $\begin{array}{l}\text { Fig. } 1 \text { Global deatr } \\
U I=\text { uncertainty int }\end{array}$ & $\begin{array}{l}\text { ranks for the top } 25 \text { causes of death } \\
\text { val, } C O P D=\text { chronic obstructive puln }\end{array}$ & $\begin{array}{l}0 \text { and 2010. In 2010, COPD rose to th } \\
\text { disease. Reproduced from Lozano et }\end{array}$ & $\begin{array}{l}\text { e third leading caus } \\
\text { al. [3]. }\end{array}$ & of death worldwide. \\
\hline
\end{tabular}

\section{Review}

\section{Diagnosing COPD using spirometry}

Spirometry is used to assess lung function in humans. The most useful measures are $\mathrm{FEV}_{1}$ (forced expiratory volume in $1 \mathrm{~s}$ ) and FVC (forced vital capacity, i.e., the volume of air expired by a full expiration). When the ratio of $\mathrm{FEV}_{1}$ to $\mathrm{FVC}$ is under 0.7 , this is referred to as an obstructive defect. The severity of COPD can also be assessed by spirometry, a value of $\mathrm{FEV}_{1}$ less than $80 \%$ predicted indicating (in the presence of a reduced $\mathrm{FEV}_{1}$ / FVC ratio) the presence of COPD. Interestingly, it has been shown that spirometry measurements also cluster within families again suggesting there is a hereditary component which may influence the development of respiratory disease $[10,11]$. Between $20-60 \%$ of phenotypic variance in lung function measures is suggested to be attributed by hereditary factors [6-9] and this is strongly correlated in twin studies [12].

\section{Environmental and genetic factors of COPD}

Smokers are characteristically prone to developing COPD; therefore smoking is a primary risk factor for developing COPD. Estimates indicate that after 25 years of smoking 30-40\% of smokers will have COPD [13]. Even non-smokers may be affected due to general exposure to air pollutants. One investigation into long term smoke particulate matter exposure revealed a significant association between an increase in exposure to small particles and a mild decrease in $\mathrm{FEV}_{1}$ across 20 years [14]. In addition, biomass emissions are also a notable risk factor globally, in general consisting of smoke inhalation via indoor pollution or occupational exposure. Genetic predisposition is also a known risk factor which increases an individual's susceptibility to developing COPD. The most commonly studied example in COPD is $\alpha 1$-antitrypsin deficiency where individuals (commonly of northern European ancestry) are homozygous for a deleterious mutation in SERPINA1 [15]. 1-2 \% of COPD cases are attributable to this mutation, which leads to enhanced neutrophil elastase activity, ultimately leading to destruction of the alveoli. Early genetic linkage analyses have indicated the existence of gene-by-smoking interactions as contributing to a decline in lung function. In those studies the logarithm of odds (LOD) score of genetic linkage was improved by restricting the analysis to smokers which suggested the existence of interaction between cigarette smoke exposure and genetic susceptibility [16]. More recently Liao et al. have more robustly explored the effects of geneby-environment interaction by using individual SNPs and genetic network approaches [17]. Both ways of analysis 
identified SNPs near gene SLC38A8 as significantly modifying the effects of occupational exposure on $\mathrm{FEV}_{1}$. Genetic network analysis alone identified genes CTLA-4, $H D A C$, and PPAR-alpha as modulating these effects. This study implied the existence of genes related to inflammatory processes which could modify the effects of occupational exposure on lung function. Readers are advised to refer to an excellent review by Molfino and Coyle which reviews the gene-environment interaction in COPD [18].

\section{Meta-analyses of GWA studies identifies genetic regions associated with $\mathrm{FEV}_{1}$}

Large scale genetic studies (genome wide association studies (GWAS)) are now able to accurately reveal associations between phenotypes (such as spirometry measures) and genetic loci. By meta-analysing many GWA studies, researchers have revealed a number of single nucleotide polymorphisms (SNPs) within/near genes which are associated with the lung function measure $\mathrm{FEV}_{1}$ (Table 1). These genes may potentially influence the development or severity of COPD and could also be important in other obstructive diseases of the lung $[19,20]$.

Five meta-analyses and one look up of candidate SNPs identified from the SpiroMeta general population were included in the overview of GWAS meta-analyses in Table 1. In 2010, back to back publications by our group [19] and others [20] showed the utility of meta-analysing GWA studies when both studies identified SNPs within the 4q24 locus to be the most significantly associated with $\mathrm{FEV}_{1}$. Hancock et al. identified 46 SNPs at this locus with the smallest $\mathrm{p}$ value for SNP rs17331332 located nearest NPNT, whilst the top SNP of our study is located in oppositely transcribed genes INTS12 and GSTCD [20, 21]. Interestingly, a look up of previously suggested candidate genes found no significant associations suggesting that genome wide approaches are the most reliable way to identify true genetic risk factors for COPD and/or lung function phenotypes [22]. In the same year Soler-Artigas et al. reported 16 novel loci associated with lung function; 5 associated with $\mathrm{FEV}_{1}, 4$ of which survived joint metaanalysis of all stages (MECOM (also known as EVI1), ZKSCAN3, CDC123, C10orf11) [23]. Subsequently in 2012, Hancock et al. identified KCNJ2/SOX9 at 17q24.3 to be associated with $\mathrm{FEV}_{1}$ [24]. Given that cigarette smoking adversely affects pulmonary function, the group conducted genome-wide joint meta-analyses of SNPs and SNP by smoking associations. GWAS have also been utilised to identify variants associated with smoking behaviour. In 2010, three pivotal publications identified loci associated with smoking behaviour. Whilst Thorgeirsson et al. identified variants in neuronal acetylcholine receptors, CHRNB3-CHRNA6 and the Cytochrome P450, CYP2A6 associated with smoking behaviour [25], Liu et al. refined the association identified at $15 \mathrm{q} 25$ [26]. In the same year the Tobacco and Genetics Consortium identified multiple loci associated with smoking behaviour [27].

More recently in 2014, Tang et al. studied longitudinal changes in lung function and mean rates of decline by smoking pattern. The strongest association with decline in $\mathrm{FEV}_{1}$ mapped to SNPs at 15q25.1 encompassing IL16/STARD5/TMC3, however, this result did not reach genome-wide significance [28]. Furthermore, Tang et al. studied rate of $\mathrm{FEV}_{1}$ change in a subsequent metaanalyses of 5 cohorts which had more than 3 measurements per participant. Interestingly, a SNP within $B A Z 2 B$ was identified at both stages [28].

\section{COPD associated genes}

In addition to the study of the genetic basis for lung function in large populations, sixteen case control studies of COPD have also been studied to try and identify SNPs in genes which are associated with COPD (Table 2). In GWA studies of COPD cohorts, SNP rs7671167, within $F A M 13 A$, was associated with chronic bronchitis, airway obstruction, emphysema and COPD susceptibility [29-32]. Additionally 9 other SNPs within FAM13A were associated with COPD [29,31-34]. This region is close to but distinct from the 4q24 locus identified by earlier studies on $\mathrm{FEV}_{1}$ and $\mathrm{FEV}_{1} / \mathrm{FVC}$ ratio. HTR4 (encoding a serotonin receptor) was also found to be associated with COPD in two separate GWA studies [35, 36]. The 4q24 locus and HTR4 are discussed in more detail in a later section.

In particular, 6 studies have found numerous SNP's at the 15q25.1 locus to be associated with COPD [30, 31, 34, $35,37,38]$. This locus encompasses 3 cholinergic nicotinic receptors (CHRNA5, CHRNA3 and CHRNAB4). However, this locus appears to exert its effects by determining an individual's risk for nicotine dependence rather than through any direct effect on the lung per se.

Current efforts within the respiratory research community are trying to decipher the biological relevance of the functions of these genes and elucidate whether pathways identified are therapeutically targetable. On comparison of the genes shown in Tables 1 and 2 presenting the top genes associated with either $\mathrm{FEV}_{1}$ (from metaanalysing GWA studies) or COPD, the most obvious priorities for further research would appear to include TNS1, genes within the 4q24 locus (FLJ20184, INTS12, GSTCD and NPNT), HHIP, HTR4 and SOX9. Within the genes listed in Table 2 it is of particular note that there are a number of SNPs in genes implicated in the control of lung development which also show evidence of association with COPD risk, namely HHIP (SHH pathway), FGF7 (Fibroblast Growth Factor pathway) and SOX9 (Wnt/ß-catenin pathway). 
Table 1 FEV 1 associated SNPs identified using GWAS meta-analyses

\begin{tabular}{|c|c|c|c|c|}
\hline Gene & Locus & SNP & Measure & Reference \\
\hline ST3GAL3 & $1 \mathrm{p} 34.1$ & rs121374475 & $\mathrm{FEV}_{1}$ decline & Tang et al. 2014 [28] \\
\hline NFIA & $1 \mathrm{p} 31.3$ & rs766488 & $\mathrm{FEV}_{1}$ decline & Tang et al. 2014 [28] \\
\hline ESRRG/GPATCH2 & $1 q 41$ & rs17698444 & $\mathrm{FEV}_{1}$ decline & Tang et al. 2014 [28] \\
\hline$B A Z 2 B$ & $2 q 24.2$ & rs12692550 & $\mathrm{FEV}_{1}$ decline and ${ }^{\mathrm{b}}$ Rate of $\mathrm{FEV}_{1}$ change & Tang et al. 2014 [28] \\
\hline FOSL2/PLB1 & $2 \mathrm{p} 23.2$ & rs10209501 & ${ }^{\mathrm{b}}$ Rate of $\mathrm{FEV}_{1}$ change & Tang et al. 2014 [28] \\
\hline TNS1 & $2 q 35$ & rs2571445 & $\mathrm{FEV}_{1}$ & Repapi et al. 2010 [19] \\
\hline HDAC4 & $2 q 37.3$ & rs12477314 & $\mathrm{FEV}_{1}$ & Soler-Artigas et al. 2011 [36] \\
\hline MECOM & $3 q 26.2$ & rs1344555 & $\mathrm{FEV}_{1}$ & Soler-Artigas et al. 2011 [36] \\
\hline FL25363/MIR4445 & $3 q 13.13$ & rs1729588 & ${ }^{\mathrm{b}}$ Rate of $\mathrm{FEV}_{1}$ change & Tang et al. 2014 [28] \\
\hline GSTCD & $4 q 24$ & rs10516526 & $\mathrm{FEV}_{1}$ & Repapi et al. 2010 [19] \\
\hline FLJ20184 & $4 q 24$ & 46 SNPs across locus & $\mathrm{FEV}_{1}$ & Hancock et al. 2010 [20] \\
\hline INTS12 & $4 q 24$ & 46 SNPs across locus & $\mathrm{FEV}_{1}$ & Hancock et al. 2010 [20] \\
\hline GSTCD & $4 q 24$ & 46 SNPs across locus & $\mathrm{FEV}_{1}$ & Hancock et al. 2010 [20] \\
\hline NPNT & $4 q 24$ & 46 SNPs across locus & $\mathrm{FEV}_{1}$ & Hancock et al. 2010 [20] \\
\hline HHIP & $4 q 31$ & rs12604628 & $\mathrm{FEV}_{1}$ & Repapi et al. 2010 [19] \\
\hline$P D E 4 D^{a}$ & $5 q 12$ & rs298028 & $\mathrm{FEV}_{1}$ & Obeidat et al. 2011 [22] \\
\hline HTR4 & $5 q 33$ & rs3995090 & $\mathrm{FEV}_{1}$ & Repapi et al. 2010 [19] \\
\hline ZKSCAN3 & $6 p 22.1$ & rs6903823 & $\mathrm{FEV}_{1}$ & Soler-Artigas et al. 2011 [23] \\
\hline MTHFD1L ${ }^{\mathrm{a}}$ & $6 q 25.1$ & rs803450 & $\mathrm{FEV}_{1}$ & Obeidat et al. 2011 [22] \\
\hline$N A T 2^{a}$ & $8 p 22$ & rs6988857 & $\mathrm{FEV}_{1}$ & Obeidat et al. 2011 [22] \\
\hline CDC123 & $10 p 13$ & rs7068966 & $\mathrm{FEV}_{1}$ & Soler-Artigas et al. 2011 [23] \\
\hline C10orf112/MALRD1 & 10p12.31 & rs10764053 & ${ }^{\mathrm{b}}$ Rate of $\mathrm{FEV}_{1}$ change & Tang et al. 2014 [28] \\
\hline C10orf11 & $10 q 22.3$ & rs11001819 & $\mathrm{FEV}_{1}$ & Soler-Artigas et al. 2011 [23] \\
\hline ME3 & $11 q 14.2$ & rs507211 & ${ }^{\mathrm{b}}$ Rate of $\mathrm{FEV}_{1}$ change & Tang et al. 2014 [28] \\
\hline CNTN5 $^{\mathrm{a}}$ & $11 q 22-q 22.2$ & rs17133553 & $\mathrm{FEV}_{1}$ & Obeidat et al. 2011 [22] \\
\hline TRPV4 $4^{\mathrm{a}}$ & $12 q 24.1$ & rs3742030 & $\mathrm{FEV}_{1}$ & Obeidat et al. 2011 [22] \\
\hline TMCO3 & $13 q 34$ & rs 2260722 & $\mathrm{FEV}_{1}$ decline & Tang et al. 2014 [28] \\
\hline SERPINA $1^{\mathrm{a}}$ & $14 q 32.13$ & rs3748312 & $\mathrm{FEV}_{1}$ & Obeidat et al. 2011 [22] \\
\hline IL16/STARD5/TMC3 & $15 q 25.1$ & rs4077833 & $\mathrm{FEV}_{1}$ decline & Tang et al. 2014 [28] \\
\hline$S V 2 B$ & $15 q 26.1$ & rs8027498 & $\mathrm{FEV}_{1}$ decline & Tang et al. 2014 [28] \\
\hline MYH11 & $16 p 13.11$ & rs8051319 & FEV 1 decline & Tang et al. 2014 [28] \\
\hline CACNG4 & $17 q 24.2$ & rs740557 & $\mathrm{FEV}_{1}$ decline & Tang et al. 2014 [28] \\
\hline KCNJ2/SOX9 & $17 q 24.3$ & rs11654749 & $\mathrm{FEV}_{1}$ & Hancock et al. 2012 [24] \\
\hline$B C L 2^{\mathrm{a}}$ & $18 q 21.3$ & rs 2850760 & $\mathrm{FEV}_{1}$ & Obeidat et al. 2011 [22] \\
\hline$M A C R O D 2^{a}$ & 20p12.1 & rs204652 & $\mathrm{FEV}_{1}$ & Obeidat et al. 2011 [22] \\
\hline
\end{tabular}

Top hits for $\mathrm{FEV}_{1}$ association seen in 6 studies of genome-wide association study meta-analyses [19, 20, 22-24, 28]

${ }^{\mathrm{a}}$ Top hits that were outside the level of significance, ${ }^{\mathrm{b}}$ In meta-analyses of 5 cohorts with over 3 measurements per participant

\section{Genetics of lung development}

Gene expression across lung development is a complex and intricately timed process. Several signalling pathways in particular are considered key for correct lung development (Table 3). Lung development is also subdivided into five distinct developmental stages (Fig. 2), each governed by specific signalling cascades (Table 4).
The mammalian respiratory system originates from the anterior foregut endoderm in the foetus for the purpose of developing an ideal structure to facilitate gas exchange. During embryogenesis and the following pseudoglandular stage the two lung buds begin a complex process of branching morphogenesis; a highly regulated process generating a tree-like structure of epithelial tubes branching 
Table 2 COPD associated SNPs identified using GWAS or candidate gene methodology

\begin{tabular}{|c|c|c|c|c|}
\hline Gene & Locus & SNP & Association/Comparison & Reference \\
\hline TGFB2 & $1 q 41$ & rs4846480 & Severe COPD vs healthy smoker & Cho et al. 2014 [34] \\
\hline TNS1 & $2 q 35$ & rs2571445 & COPD susceptibility & Soler-Artigas et al. 2011 [36] \\
\hline PID1 & $2 q 36.3$ & rs10498230 & $\mathrm{FEV}_{1} / \mathrm{FVC}$ associated measure - COPD susceptibility & Castaldi et al. 2011 [96] \\
\hline PID1 & $2 q 36.3$ & rs 1435867 & $\mathrm{FEV}_{1} / \mathrm{FVC}$ associated measure - COPD susceptibility & Castaldi et al. 2011 [96] \\
\hline PID1 & $2 q 36.3$ & rs16825116 & Lung function gene associated with COPD susceptibilty & Kim et al. 2014 [33] \\
\hline FAM13A & $4 q 22.1$ & rs2869967 & Chronic Bronchitis COPD vs smoker control & Lee et al. 2014 [29] \\
\hline FAM13A & $4 q 22.1$ & rs2045517 & Chronic Bronchitis COPD vs smoker control & Lee et al. 2014 [29] \\
\hline FAM13A & $4 q 22.1$ & rs7671167 & Chronic Bronchitis COPD vs smoker control & Lee et al. 2014 [29] \\
\hline FAM13A & $4 q 22.1$ & rs7671167 & Airway obstruction in COPD & Cho et al. 2012 [32] \\
\hline FAM13A & $4 q 22.1$ & rs7671167 & Emphysema in COPD cohort & Pillai et al. 2010 [30] \\
\hline FAM13A & $4 q 22.1$ & rs7671167 & COPD susceptibility & Cho et al. 2010 [31] \\
\hline FAM13A & $4 q 22.1$ & rs1903003 & COPD susceptibility & Cho et al. 2010 [31] \\
\hline FAM13A & $4 q 22.1$ & rs2904259 & Chronic Bronchitis COPD vs smoker control & Lee et al. 2014 [29] \\
\hline FAM13A & $4 q 22.1$ & rs2609264 & Lung function gene associated with COPD susceptibilty & Kim et al. 2014 [33] \\
\hline FAM13A & $4 q 22.1$ & rs2609261 & Lung function gene associated with COPD susceptibilty & Kim et al. 2014 [33] \\
\hline FAM13A & $4 q 22.1$ & rs 2609260 & Lung function gene associated with COPD susceptibilty & Kim et al. 2014 [33] \\
\hline FAM13A & $4 q 22.1$ & rs4416442 & Moderate to severe and severe COPD vs healthy smoker & Cho et al. 2014 [34] \\
\hline FAM13A & $4 q 22.1$ & rs1964516 & Airway obstruction in COPD & Cho et al. 2012 [32] \\
\hline FL20184 & $4 q 24$ & rs17035960 & FEV ${ }_{1}$ associated measure - COPD susceptibility & Castaldi et al. 2011 [96] \\
\hline FL20184 & $4 q 24$ & rs17036052 & $\mathrm{FEV}_{1}$ associated measure - COPD susceptibility & Castaldi et al. 2011 [96] \\
\hline INTS12 & $4 q 24$ & rs11727189 & $\mathrm{FEV}_{1}$ associated measure - COPD susceptibility & Castaldi et al. 2011 [96] \\
\hline INTS12 & $4 q 24$ & rs17036090 & $\mathrm{FEV}_{1}$ associated measure - COPD susceptibility & Castaldi et al. 2011 [96] \\
\hline GSTCD & $4 q 24$ & rs10516526 & COPD susceptibility & Soler-Artigas et al. 2011 [36] \\
\hline GSTCD & $4 q 24$ & rs10516526 & $\mathrm{FEV}_{1}$ associated measure - COPD susceptibility & Castaldi et al. 2011 [96] \\
\hline GSTCD & $4 q 24$ & rs11097901 & $\mathrm{FEV}_{1}$ associated measure - COPD susceptibility & Castaldi et al. 2011 [96] \\
\hline GSTCD & $4 q 24$ & rs11728716 & FEV 1 associated measure - COPD susceptibility & Castaldi et al. 2011 [96] \\
\hline NPNT & $4 q 24$ & rs17036341 & $\mathrm{FEV}_{1}$ associated measure - COPD susceptibility & Castaldi et al. 2011 [96] \\
\hline NPNT & $4 q 24$ & rs17331332 & $\mathrm{FEV}_{1}$ associated measure - COPD susceptibility & Castaldi et al. 2011 [96] \\
\hline HHIP & $4 q 31.21$ & rs13141641 & Moderate to severe and severe COPD vs healthy smoker & Cho et al. 2014 [34] \\
\hline HHIP & $4 q 31.21$ & rs 12504628 & COPD susceptibility & Soler-Artigas et al. 2011 [36] \\
\hline HHIP & $4 q 31.21$ & rs13118928 & $\mathrm{FEV}_{1} / \mathrm{FVC}$, Emphysema and Exacerbations in COPD cohort & Pillai et al. 2010 [30] \\
\hline HHIP & $4 q 31.21$ & rs13118928 & COPD susceptibility & Cho et al. 2010 [31] \\
\hline HHIP & $4 q 31.21$ & rs13118928 & COPD susceptibility & van Durme et al. 2010 [103] \\
\hline HHIP & $4 q 31.21$ & rs1828591 & COPD susceptibility & van Durme et al. 2010 [103] \\
\hline HTR4 & $5 q 32$ & rs7733088 & Airway obstruction & Wilk et al. 2012 [35] \\
\hline HTR4 & $5 q 32$ & rs3995090 & COPD susceptibility & Soler-Artigas et al. 2011 [36] \\
\hline ADAM19 & $5 q 33$ & rs2277027 & $\mathrm{FEV}_{1} / \mathrm{FVC}$ associated measure - COPD susceptibility & Castaldi et al. 2011 [96] \\
\hline ADAM19 & $5 q 33$ & rs 1422795 & $\mathrm{FEV}_{1} / \mathrm{FVC}$ associated measure - COPD susceptibility & Castaldi et al. 2011 [96] \\
\hline PPT2 & $6 \mathrm{p} 21$ & rs10947233 & $\mathrm{FEV}_{1} / \mathrm{FVC}$ associated measure - COPD susceptibility & Castaldi et al. 2011 [96] \\
\hline AGER & $6 p 21$ & rs2070600 & $\mathrm{FEV}_{1} / \mathrm{FVC}$ associated measure - COPD susceptibility & Castaldi et al. 2011 [96] \\
\hline ACN9 & $7 q 21.3$ & rs10231916 & Lung function gene associated with COPD susceptibilty & Kim et al. 2014 [33] \\
\hline ACN9 & $7 q 21.3$ & rs10229181 & Lung function gene associated with COPD susceptibilty & Kim et al. 2014 [33] \\
\hline RHOBTB1 - TMEM26 & $10 \mathrm{q} 21.2$ & rs10761570 & Decline in $\mathrm{FEV}_{1}$ in mild/moderate COPD & Hansel et al. 2013 [104] \\
\hline RHOBTB1 - TMEM26 & 10q21.2 & rs7911302 & Decline in $\mathrm{FEV}_{1}$ in mild/moderate COPD & Hansel et al. 2013 [104] \\
\hline
\end{tabular}


Table 2 COPD associated SNPs identified using GWAS or candidate gene methodology (Continued)

\begin{tabular}{|c|c|c|c|c|}
\hline EFCAB4A & $11 \mathrm{p} 15$ & rs34391416 & Chronic Bronchitis COPD vs smoker control & Lee et al. 2014 [29] \\
\hline CHID1 & $11 \mathrm{p} 15$ & rs147862429 & Chronic Bronchitis COPD vs smoker control & Lee et al. 2014 [29] \\
\hline ANO3 & $11 \mathrm{p} 14.2$ & rs7119465 & Lung function gene associated with COPD susceptibilty & Kim et al. 2014 [33] \\
\hline MMP12 & $11 \mathrm{q} 22.2$ & rs626750 & Severe COPD vs healthy smoker & Cho et al. 2014 [34] \\
\hline BICD1 & $12 \mathrm{p} 11.21$ & rs10844154 & Emphysematous COPD & Kong et al. 2011 [105] \\
\hline BICD1 & $12 \mathrm{p} 11.21$ & rs161976 & Emphysematous COPD & Kong et al. 2011 [105] \\
\hline LOC100128066 - TTC6 & $14 q 21.1$ & rs177852 & Decline in $\mathrm{FEV}_{1}$ in mild/moderate COPD & Hansel et al. 2013 [104] \\
\hline RIN3 & $14 q 32.12$ & rs754388 & Moderate to severe and severe COPD vs healthy smoker & Cho et al. 2014 [34] \\
\hline IREB2 & $15 q 25.1$ & rs1062980 & COPD susceptibility & Brehm et al. 2011 [37] \\
\hline IREB2 & $15 q 25.1$ & rs13180 & COPD susceptibility & Brehm et al. 2011 [37] \\
\hline IREB2 & $15 q 25.1$ & rs8034191 & COPD susceptibility & Brehm et al. 2011 [37] \\
\hline IREB2 & $15 q 25.1$ & rs265606 & COPD susceptibility & Brehm et al. 2011 [37] \\
\hline PSMA4 & $15 q 25.1$ & rs2036534 & COPD susceptibility & Brehm et al. 2011 [37] \\
\hline AGPHD1 - CHRNA3/5 & $15 q 25.1$ & 11 SNPS & Airway obstruction in ever smoker & Wilk et al. 2012 [35] \\
\hline CHRNA5 & $15 q 25.1$ & rs17486278 & Airway obstruction in all ever/never smoker & Wilk et al. 2012 [35] \\
\hline CHRNA3/5 & $15 q 25.1$ & rs8034191 & $\mathrm{FEV}_{1}, \mathrm{FEV}_{1} / \mathrm{FVC}$ and Emphysema in COPD cohort & Pillai et al. 2010 [30] \\
\hline CHRNA3 & $15 q 25.1$ & rs12914385 & COPD susceptibility & Brehm et al. 2011 [37] \\
\hline CHRNA3 & $15 q 25.1$ & rs 1051730 & COPD susceptibility & Brehm et al. 2011 [37] \\
\hline CHRNA3 & $15 q 25.1$ & rs12914385 & Moderate to severe and severe COPD & Cho et al. 2014 [34] \\
\hline CHRNA3/CHRNA5/IREB2 & $15 q 25.1$ & rs1062980 & COPD susceptibility & Cho et al. 2010 [31] \\
\hline CHRNA3/CHRNA5/IREB2 & $15 q 25.1$ & rs13180 & COPD susceptibility & Cho et al. 2010 [31] \\
\hline CHRNA3/5 & $15 q 25.1$ & rs8034191 & COPD susceptibility & Pillai et al. 2009 [38] \\
\hline CHRNA3/5 & $15 q 25.1$ & rs1051730 & COPD susceptibility & Pillai et al. 2009 [38] \\
\hline FGF7 & $15 q 21.2$ & rs12591300 & COPD susceptibility & Brehm et al. 2011 [37] \\
\hline FGF7 & $15 q 21.2$ & rs4480740 & COPD susceptibility & Brehm et al. 2011 [37] \\
\hline DTWD1 & $15 q 21.2$ & rs17404727 & COPD susceptibility & Brehm et al. 2011 [37] \\
\hline MCTP2 & $15 q 26.2$ & rs8031759 & Lung function gene associated with COPD susceptibilty & Kim et al. 2014 [33] \\
\hline AKAP1 & $17 q 22$ & rs886282 & Lung function gene associated with COPD susceptibilty & Kim et al. 2014 [33] \\
\hline SOX9 & $17 q 24.3$ & rs17178251 & Lung function gene associated with COPD susceptibilty & Kim et al. 2014 [33] \\
\hline SOX9 & $17 q 24.3$ & rs17765644 & Lung function gene associated with COPD susceptibilty & Kim et al. 2014 [33] \\
\hline SOX9 & $17 q 24.3$ & rs11870732 & Lung function gene associated with COPD susceptibilty & Kim et al. 2014 [33] \\
\hline RAB4B - EGLN2 & $19 q 13$ & rs7937 & Airway obstruction in COPD & Cho et al. 2012 [32] \\
\hline$R A B 4 B-E G L N 2$ & $19 q 13$ & rs2604894 & Airway obstruction in COPD & Cho et al. 2012 [32] \\
\hline PDE9A & $21 \mathrm{q} 22.3$ & rs2269145 & Lung function gene associated with COPD susceptibilty & Kim et al. 2014 [33] \\
\hline
\end{tabular}

COPD gene associations in the literature [29-38, 96, 103-105]

by dichotomy [39]. Branching is driven by a number of signalling pathways communicating between the mesenchyme and the epithelium, directing the growth and patterning of lung buds (Table 3). Branching morphogenesis is a critical time during lung development determining lung resistance and compliance in adult life. As discussed above, these determinants of airway function can be quantified by $\mathrm{FEV}_{1}$ and $\mathrm{FEV}_{1} / \mathrm{FVC}$ measures, and therefore polymorphic variation in genes active during the period of airway branching could feasibly be linked to adult lung function [40].
Of the highly complex signalling systems; Sonic Hedgehog (SHH) and Fibroblast growth factor (FGF) are considered two of the primary signalling pathways critical for lung development [39]. The critical role of separation of the trachea from oesophagus is influenced by SHH signalling and FGF patterning, with both pathways initially involved in determining distal airway development [41, 42]. Furthermore, the transcription factor Nkx2.1 marks the future oesophagus and Wnt signalling works alongside to specify lung fate [43]. In relation to lung diseases, despite regeneration and repair of injured 
Table 3 Key signalling pathways involved in mammalian lung development

\begin{tabular}{|c|c|}
\hline Signalling pathway & Role in lung development \\
\hline \multirow[t]{4}{*}{ Fibroblast Growth Factor (FGF) } & Role in the rate of airway bud extension \\
\hline & Involved in the formation of new alveoli \\
\hline & Limits proliferation or migration of branching epithelium \\
\hline & FGF among the signals that confer anterior-posterior identity \\
\hline \multirow[t]{3}{*}{ Sonic Hedgehog (SHH) } & Important in regulating lung cell proliferation and asymmetry \\
\hline & Negatively regulates FGF10 \\
\hline & Limits lung bud growth \\
\hline \multirow[t]{2}{*}{ NK2 homeobox (NKX2.1) } & Important in formation of tracheo-oesophageal septum \\
\hline & Essential for initiating branching \\
\hline \multirow[t]{2}{*}{ Notch } & Key role in cell-cell communication during lung development \\
\hline & Promotes proximal lung cell fates \\
\hline \multirow[t]{3}{*}{ Planar Cell Polarity (PCP) } & Drives polarisation of cells \\
\hline & Required for branching \\
\hline & Involved in determining lung architecture \\
\hline \multirow[t]{2}{*}{ Retinoic Acid } & Promotes growth of the primary lung buds \\
\hline & Down-regulates TGF $\beta$ signalling \\
\hline \multirow{3}{*}{$\begin{array}{l}\text { Transforming growth factor } \beta / \text { Bone morphogenic protein (BMP)- } \\
\text { SMAD (TGF } \beta / B M P-S M A D)\end{array}$} & Can inhibit/stimulate lung morphogenesis \\
\hline & Contributes to distal lung development \\
\hline & BMP among the signal that confer anterior-posterior identity \\
\hline \multirow[t]{2}{*}{ Wnt/B-catenin } & Negatively regulates branching \\
\hline & Involved in developing peripheral airways \\
\hline
\end{tabular}

Lung development and signalling pathway information was collected from many sources [39, 42, 43, 106-120]

lung tissue not currently being fully understood, it can be hypothesised that events would follow the same or similar pathways as those used during lung development outlined here. Therefore, it is important to understand any potential associations between genes involved in both COPD and lung development. For instance, of the genes associated with COPD in Table 2, SOX9, HHIP, $M M P 12, H T R 4$ and FGF7 also have distinct roles during lung development. SOX9, HHIP, FGF7 are involved in airway branching morphogenesis typically with expression levels peaking during the embryonic and pseudoglandular stages [44-53]. SOX9 expression can be modulated by a number of key pathways including: $\mathrm{HH}$, Wnt/ $\beta$-catenin, Notch, TGF- $\beta$, NFKB, BMP and FGF [54]. Additional genes of interest due to varying expression patterns across and associations with lung development include: EFCAB4A, CHID1, ANO3, AKAP1, TGFB2, GSTCD and NPNT [20, 21, 55-60]. These genes have been demonstrated to be significantly associated with COPD (Table 2) and show preliminary evidence for involvement with lung development, with a common feature of varied expression during branching morphogenesis stages. SNPs in the genes AGER, HHIP and TNS1 are associated with reduced airway calibre and may be involved in lung development and growth [47]. In summary therefore, it appears that many of the genes which potentially underlie the associations seen in GWA studies of lung function and/or COPD are involved in control of lung development and potentially remodelling. Some additional support for a role in lung development comes from the observation that associations with lung function are present across the age spectrum, although the number of studies in younger age groups and children to date has been small. Furthermore, the mechanism of action of potential susceptibility genes can vary, where genetic susceptibility could lead to dysregulated lung development (as discussed) during childhood or adolescence or may lead to enhanced decline of $\mathrm{FEV}_{1}$ in adulthood, which has long been considered the most common indicator of COPD [61-63]. A recent study has indicated that approximately half of the individuals who meet the criteria for COPD in later life (COPD at grade 2 or higher according to the Global Initiative for Chronic Obstructive Lung Disease (GOLD) grading system) [4] do attain normal maximal $\mathrm{FEV}_{1}$ in young adulthood and have accelerated rates of decline [64]. However, the authors also suggest that a substantial proportion of patients with COPD may not have had a rapid decline in $\mathrm{FEV}_{1}$, as the second half of participants followed a more typical decline in $\mathrm{FEV}_{1}$ starting from a low initial value of 


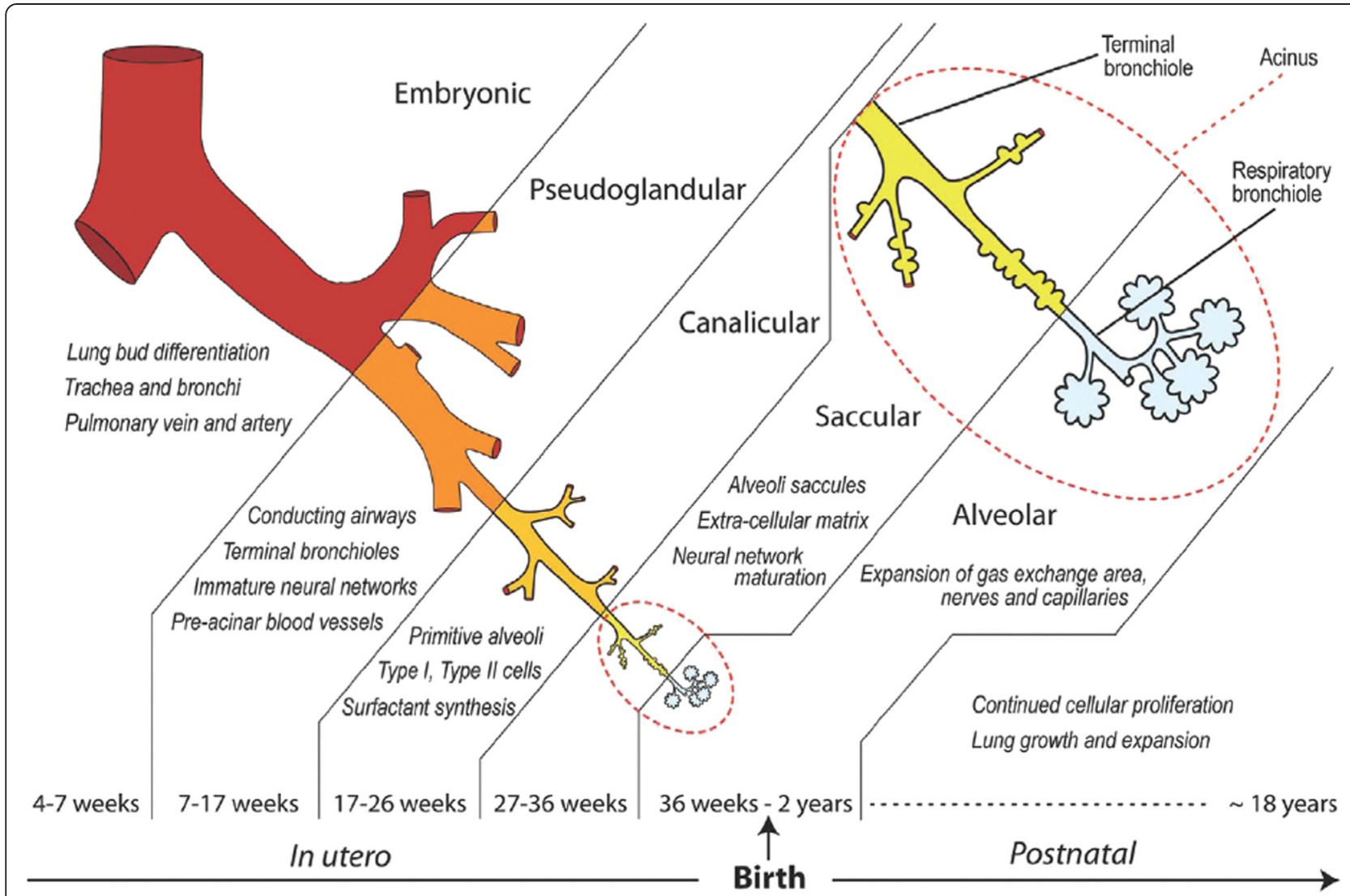

Fig. 2 Five stages of lung development. Stages of lung development in humans: Diagrammatic timeline of the developmental organisation of the mammalian respiratory system. At the embryonic stage, the major airways are formed. During the canalicular stage epithelial differentiation occurs and the air-blood barrier is formed. In the saccular stage of lung development, air spaces expand and finally at the alveolar stage, secondary septation occurs. Reprinted from [102] with permission from Elsevier, copyright (2007).

$\mathrm{FEV}_{1}$. Hence this may indicate populations of COPD patients with different rates of decline in $\mathrm{FEV}_{1}$ potentially a consequence of dysregulated lung development or an earlier rapid decline in $\mathrm{FEV}_{1}$ [64]. Additionally, it can be reasoned that the most important determinant of maximally attained lung function later in life is lung function measurement at a younger age, as shown by several studies involving children and young adults [65-68] which may indicate initial dysregulated lung development.

Also, in 2004, de Marco et al. have proposed that the origin of COPD could be from an earlier age group than is usually believed, as a considerable percentage of subjects aged 20-44 years reported already suffering from COPD and GOLD stage 0 chronic symptoms [69] and later the group identified a subgroup of young adult subjects with a high risk of developing COPD, independently of smoking habits [70].

\section{Epigenetics considerations in lung function and COPD}

Epigenetics is commonly defined as heritable changes to gene expression, independent of changes to DNA sequence. Whereas genetic changes in DNA sequence involve variation of nucleotides, epigenetic changes alter methylation patterns at $\mathrm{CpG}$ sites or modifications to chromatin, influencing the level of DNA folding and therefore the levels of transcription at a particular gene. This area of research investigates the link between lifetime exposures of parents with the influence these may have on epigenetic patterns in children. Despite epigenetics consisting of dynamic and modifiable processes which can change over time, it is of key interest as these changes can persist across generations [71].

Typically, COPD is classed as a disease of later life, although as discussed above predisposition to COPD may also have an early origin during lung development. In particular, smoking during pregnancy has been investigated to understand the effects of smoking exposure on lung development, as it is suggested that susceptibility to environmental factors is highest during this period and changes may contribute to adult airflow limitation [72]. Furthermore, maternal smoking has been demonstrated to be associated with lower adult lung volume independent to post-natal exposure and of personal 
Table 4 Stages and events during lung development in humans and mice

\begin{tabular}{|c|c|c|c|}
\hline Developmental stage & Human gestation age & Mouse gestation age & Lung development events \\
\hline \multirow[t]{3}{*}{ Embryonic } & \multirow[t]{3}{*}{ 4-7 weeks } & \multirow[t]{3}{*}{ 9-14 days } & Septation of trachea from oesophagus \\
\hline & & & Lung bud forms two main bronchi and individual lobes \\
\hline & & & $\begin{array}{l}\text { Supporting structures are formed including bronchial cartilage } \\
\text { and smooth muscle }\end{array}$ \\
\hline \multirow[t]{2}{*}{ Pseudoglandular } & \multirow[t]{2}{*}{ 5-17 weeks } & \multirow[t]{2}{*}{ 14-16.5 days } & Branching morphogenesis begins \\
\hline & & & $\begin{array}{l}\text { Proximal airway epithelial and mesenchymal differentiation } \\
\text { occurs }\end{array}$ \\
\hline \multirow[t]{5}{*}{ Canalicular } & \multirow[t]{5}{*}{ 16-26 weeks } & \multirow[t]{5}{*}{ 16.5-17.5 days } & Further branching \\
\hline & & & Vascularisation and angiogenesis occurs along the airway \\
\hline & & & Rapid increase in capillary numbers \\
\hline & & & Respiratory bronchioles and alveolar ducts form \\
\hline & & & Type II alveolar epithelial cells differentiate \\
\hline \multirow[t]{6}{*}{ Saccular } & \multirow[t]{6}{*}{ 24-36 weeks } & \multirow[t]{6}{*}{17.5 days to postnatal day 5} & Type I alveolar epithelial cells differentiate \\
\hline & & & Type II alveolar epithelial cells maturation \\
\hline & & & Air sacs are developed \\
\hline & & & Lymphatic network develops \\
\hline & & & Surfactant begins to be produced \\
\hline & & & Initial stage of primary septation for formation of alveoli occurs \\
\hline \multirow[t]{3}{*}{ Alveolar } & \multirow[t]{3}{*}{36 weeks to childhood } & \multirow[t]{3}{*}{ Postnatal day 5-30 } & Secondary septation produces alveoli \\
\hline & & & Increasing levels of surfactant produced \\
\hline & & & Majority of gas exchange surface is formed \\
\hline
\end{tabular}

Information on the stages of human and mouse lung development was collected from many sources $[42,107,121,122]$

smoking [72-76]. Of the wide range of components in tobacco smoke nicotine is thought to be the key component which alters lung development, principally because it is easily transferred to the foetus in utero in circulating blood [77-81]. Importantly, approximately $12-22 \%$ of women smoke during pregnancy [82-87]. Data from animal studies and observations in humans show that smoking during pregnancy is associated with lower lung function in offspring and increases in airway smooth muscle, decreasing alveolar surface area and collagen deposition [78, 79, 88, 89]. Effects influencing lung function such as these can be attributable to epigenetic changes which may lead to a predisposition to developing COPD. For instance, exposure to nicotine in utero has been demonstrated to increase DNA methylation and acetylation in the foetus, which would be predicted to produce down-regulation and up-regulation of transcriptional activity, respectively, in the relevant target genes [77].

However, few studies have been performed identifying alterations at specific epigenetic markers in response to maternal smoking and COPD. Nevertheless, an interesting direction may be in the form of altered methylation patterns in repetitive elements across the genome. In 2009, Breton et al. demonstrated that pre-natal smoking has been associated with methylation patterns in repetitive elements, such as AluYb8, also in conjunction with null genotypes in genes involved in tobacco smoke metabolism (GSTM1 and GSTP1) [90]. This study suggests differential methylation changes may potentially be dependent upon the genotype of a foetus, hence determining the level of susceptibility to smoke induced epigenetic alterations [90]. The group also showed that smoking during pregnancy was associated with global hypomethylation, suggested to lead to chromosomal instability [90].

With the growing interest in nicotine replacement therapy (NRT) as a seemingly healthier alternative to smoking, the evidence outlined here is a reminder that use of NRT may not be a safe alternative to smoking during pregnancy $[91,92]$, as NRT would still be predicted to exert epigenetic effects which could alter lung development. Furthermore, maternal smoking has been found to synergise with personal smoking to increase airflow limitation and risk for development of COPD [75].

Characterisation of INTS12, GSTCD and HTR4: examples of genes with potential roles in lung development

We have recently provided evidence indicating the possible role of genetic variation near or at the integrator complex subunit 12 (INTS12, 4q24), as influencing lung function measures [21]. We reported that there is a 
significant positive correlation between INTS12 expression in lung tissue and percent predicted $\mathrm{FEV}_{1}$. The same was true for the nearby Glutathione S-transferase, C-terminal domain containing gene, GSTCD, and we hypothesised that these genes share the same promoter region due to the fact that they are co-ordinately transcribed. The two genes are also co-expressed in cells of the lung and whole lung tissue. Interrogation of the publically available ENCODE dataset revealed that the presumed shared promoter contains $\mathrm{CpG}$ islands as well as transcription factor binding sites. Most importantly, SNPs that are genome-wide significant for lung function are in cis-eQTL with INTS12 expression in various tissue types and this was not observed for GSTCD nor for any gene in strong linkage disequilibrium (LD) with INTS12. By immunohistochemistry of fixed human sections, we have previously shown that GSTCD protein expression was ubiquitous, whereas INTS12 expression was predominantly in epithelial cells and pneumocytes. During human fetal lung development, GSTCD protein expression was observed to be highest at the earlier pseudoglandular stage (10-12 weeks) compared with the later canalicular stage (17-19 weeks), whereas INTS12 expression levels did not alter throughout these stages. Although this work demonstrates potential roles of INTS12 and GSTCD as drivers of the association signal for lung function, much more work is required to ultimately bridge the gap between the 4q24 GWA study findings and how these influence lung function. A separate gene our research group has actively studied is the lung function and COPD associated serotonin receptor, HTR4. We identified that the protein level of HTR4 increased throughout lung development; however HTR4 was expressed only at very low mRNA and protein levels in adult lung [50], again suggesting a potential role in lung development.

\section{Models to study candidate lung function/COPD genes: new approaches}

As we have noted, although GWA studies have been successful at detecting genomic loci harbouring variants predicting variation in lung function measures and risk of COPD, these genetic associations are usually limited to identifying fairly broad genomic regions and are incapable of distinguishing causal variants from non-causal variants [93]. Therefore despite the unprecedented success of GWA studies, the therapeutic and functional translation of these studies is still in its infancy. There are a number of experimental approaches and models that may be used to functionally translate genetic findings. These methods can help in dissecting the genetic association signals for the currently considered respiratory phenotypes and identify underlying alleles and biological pathways that are important in lung function and COPD. Computational methods can be used to combine experimentally generated regulatory information of the human genome, such as ChIP-seq (chromatin immuno-precipitation sequencing) generated binding sites or gene expression Quantitative Trait Loci (eQTL), with respiratory loci [93, 94]. The classical scheme of following up GWA study associations concentrates on manipulation of single genes (for example generating transgenic mice which have the gene deleted or overexpressed) but this method is inevitably slow. However, given genetic association data suggests the presence of a multitude of gene variants on different chromosomes predicting the disease risk or lung function measure outcome $[7,19,36,95,96]$. Recently, the development of the CRISPR-Cas9 activation system, which allows simultaneous enhancement of endogenous expression of multiple genes, may speed up functional follow up of key genetic variants [97]. Additionally, enhancing endogenous gene expression from a natural promoter is more likely to recapitulate the splicing complexity than the traditional transient or stable recombinant DNA transfection approach [97]. RNA interference (RNAi) gene silencing has successfully been used to knock down genes of interest and following downstream analyses, novel gene functions have been identified. However, with RNAi-based approaches, the data requires in depth complex analysis. Ideally, more than one siRNA or shRNA could be utilised due to the degree of false positive observations, which may obscure true results with off-target silencing effects [98]. This limitation can also be addressed with the advent of CRISPR and TALEN gene editing technology which allows generation of specific gene knock-out cells with the potential for several individual gene knock-outs in combination [99]. Of note, decreases in the cost of next generation high-throughput sequencing has addressed a number of limitations faced by microarray-based approaches and allows effective discovery of biological pathways underpinning respiratory phenotypes, for example by RNAsequencing and CHIP sequencing approaches [100]. This information could be used to make informed decisions about relevant cellular assays post genetic manipulation. Investigating respiratory phenotypes in lung tissue from specific gene knockout mice is also a valuable in vivo approach that can effectively complement in vitro work [101].

\section{Conclusions}

In conclusion, recent advances in large GWA studies and meta-analysis of results obtained across different studies has led to the identification of a large number of loci which predict lung function variability. An increasing number of these loci have also been demonstrated to show association with COPD risk per se. However, despite these advances, only a small proportion of the variability in lung function can be explained by the genetic 
variants described to date. This suggests many other variants are yet to be uncovered which may also contribute to the genetic basis of airflow obstruction. It is notable that many of the genetic regions which have been identified to date harbour genes which play an important role in lung development. Whether or not this means these genes are less likely to be useful targets for therapeutic manipulation remains to be defined. However, there is no doubt that understanding the role of these genes in the regulation of lung function will be key to improving our knowledge of the pathophysiology of COPD and other diseases characterised by airflow obstruction.

The observation that genes associated with lung function and COPD and also showing evidence of differential expression during lung development makes them good candidates playing critical roles in embryological lung development. However, more studies are warranted to demonstrate that through carefully controlled experiments SNP mutagenesis in those genes or whole gene knockout models display effects on lung morphogenesis or activity. If shown to be the case it would give more credence to the 'Dutch hypothesis' stating that COPD and asthma are essentially different manifestation of the same disease process. This is because originally this hypothesis was based on the observation that there is a fluent development from bronchitis in youth to a more asthmatic picture in adults which then further develops into bronchitis among more elderly patients. Therefore existence of genetic variants predisposing to pathobiology of lung development may be expected under this scenario.

\section{Abbreviations \\ ChIP-Seq: chromatin immunoprecipitation sequencing; COPD: chronic obstructive pulmonary disease; CRISPR: clustered regularly interspaced short palindromic repeats; ENCODE: Encyclopedia of DNA Elements; eQTL: expression Quantitative trait loci; FEV $_{1}$ : forced expiratory volume in 1 second; FGF: Fibroblast growth factor; FVC: forced vital capacity; GWA: genome-wide association; GWAS: genome-wide association study; NRT: nicotine replacement therapy; SHH: Sonic Hedgehog; SNP: single nucleotide polymorphism; TALEN: transcription activator-like effector nuclease.}

\section{Competing interests}

The authors declare that they have no competing interests.

\section{Authors' contributions}

SM and IPH planned the content of the review, KP, SM and AKK searched and reviewed the literature and drafted the review. All authors contributed to the final version. All authors read and approved the final manuscript.

\section{Acknowledgements}

Work in the authors' laboratory is funded in part by a programme grant from the MRC (grant number G1000861).

Received: 17 June 2015 Accepted: 10 November 2015

Published online: 27 November 2015

\section{References}

1. Mathers C, Boerma T, Ma Fat D. The global burden of disease: 2004 update. Geneva, Switzerland: WHO press; 2008.
2. Rudolf M. National Clinical Guideline Centre, Chronic obstructive pulmonary disease: management of chronic obstructive pulmonary disease in adults in primary and secondary care. London: National Clinical Guideline Centre; 2010.

3. Lozano R, Naghavi M, Foreman K, Lim S, Shibuya K, Aboyans V, et al. Global and regional mortality from 235 causes of death for 20 age groups in 1990 and 2010: a systematic analysis for the Global Burden of Disease Study 2010. Lancet. 2012;380(9859):2095-128. doi:10.1016/S0140-6736(12)61728-0.

4. Vestbo J, Hurd SS, Agusti AG, Jones PW, Vogelmeier C, Anzueto A, et al. Global strategy for the diagnosis, management, and prevention of chronic obstructive pulmonary disease: GOLD executive summary. American Journal of Respiratory and Critical Care Medicine. 2013;187(4):347-65. doi:10.1164/ rccm.201204-0596PP.

5. Shahab L, Jarvis MJ, Britton J, West R. Prevalence, diagnosis and relation to tobacco dependence of chronic obstructive pulmonary disease in a nationally representative population sample. Thorax. 2006;61(12):1043-7. doi:10.1136/thx.2006.064410.

6. Pauwels RA, Buist AS, Ma P, Jenkins CR, Hurd SS, Committee GS. Global strategy for the diagnosis, management, and prevention of chronic obstructive pulmonary disease: National Heart, Lung, and Blood Institute and World Health Organization Global Initiative for Chronic Obstructive Lung Disease (GOLD): executive summary. Respiratory Care. 2001;46(8):798-825.

7. Lewitter Fl, Tager IB, McGue M, Tishler PV, Speizer FE. Genetic and environmental determinants of level of pulmonary function. American Journal of Epidemiology. 1984;120(4):518-30.

8. Palmer LJ, Knuiman MW, Divitini ML, Burton PR, James AL, Bartholomew HC, et al. Familial aggregation and heritability of adult lung function: results from the Busselton Health Study. The European Respiratory Journal. 2001; 17(4):696-702

9. DeMeo DL, Silverman EK. Genetics of chronic obstructive pulmonary disease. Seminars in Respiratory and Critical Care Medicine. 2003;24(2):151-60. doi:10.1055/s-2003-39014.

10. Wilk JB, Chen TH, Gottlieb DJ, Walter RE, Nagle MW, Brandler BJ, et al. A genome-wide association study of pulmonary function measures in the Framingham Heart Study. PLoS Genetics. 2009;5(3):e1000429. doi:10.1371/journal.pgen.1000429.

11. Zhai G, Valdes AM, Cherkas L, Clement G, Strachan D, Spector TD. The interaction of genes and smoking on forced expiratory volume: a classic twin study. Chest. 2007;132(6):1772-7. doi:10.1378/chest.07-1438.

12. Hallberg J, lliadou A, Anderson M, de Verdier MG, Nihlen U, Dahlback M, et al. Genetic and environmental influence on lung function impairment in Swedish twins. Respiratory Research. 2010;11:92. doi:10.1186/1465-9921-11-92.

13. Lokke A, Lange P, Scharling H, Fabricius P, Vestbo J. Developing COPD: a 25 year follow up study of the general population. Thorax. 2006;61(11):935-9. doi:10.1136/thx.2006.062802.

14. Abbey DE, Burchette RJ, Knutsen SF, McDonnell WF, Lebowitz MD, Enright PL. Long-term particulate and other air pollutants and lung function in nonsmokers. American Journal of Respiratory and Critical Care Medicine. 1998;158(1):289-98. doi:10.1164/ajrccm.158.1.9710101.

15. Primhak RA, Tanner MS. Alpha-1 antitrypsin deficiency. Archives of Disease in Childhood. 2001;85(1):2-5.

16. Silverman EK, Palmer L, Mosley JD, Barth M, Senter JM, Brown A, et al. Genomewide linkage analysis of quantitative spirometric phenotypes in severe early-onset chronic obstructive pulmonary disease. Am J Hum Genet. 2002;70(5):1229-39. doi:10.1086/340316.

17. Liao SY, Lin X, Christiani DC. Gene-environment interaction effects on lung function- a genome-wide association study within the Framingham heart study. Environ Health. 2013;12:101. doi:10.1186/1476-069X-12-101.

18. Molfino NA, Coyle AJ. Gene-environment interactions in chronic obstructive pulmonary disease. Int J Chron Obstruct Pulmon Dis. 2008:3(3):491-7.

19. Repapi E, Sayers I, Wain LV, Burton PR, Johnson T, Obeidat M, et al. Genome-wide association study identifies five loci associated with lung function. Nature Genetics. 2010;42(1):36-44. doi:10.1038/ng.501.

20. Hancock DB, Eijgelsheim M, Wilk JB, Gharib SA, Loehr LR, Marciante KD, et al. Meta-analyses of genome-wide association studies identify multiple loci associated with pulmonary function. Nature Genetics. 2010;42(1):45-52. doi: 10.1038/ng.500.

21. Obeidat M, Miller S, Probert K, Billington CK, Henry AP, Hodge E, et al. GSTCD and INTS12 regulation and expression in the human lung. PloS One. 2013;8(9):e74630. doi:10.1371/journal.pone.0074630

22. Obeidat M, Wain LV, Shrine N, Kalsheker N, Soler Artigas M, Repapi E, et al. A comprehensive evaluation of potential lung function associated genes in 
the SpiroMeta general population sample. PloS One. 2011;6(5):e19382. doi:10.1371/journal.pone.0019382.

23. Soler Artigas M, Loth DW, Wain LV, Gharib SA, Obeidat M, Tang W, et al. Genomewide association and large-scale follow up identifies 16 new loci influencing lung function. Nature Genetics. 2011;43(11):1082-90. doi:10.1038/ng.941.

24. Hancock DB, Artigas MS, Gharib SA, Henry A, Manichaikul A, Ramasamy A, et al. Genome-wide joint meta-analysis of SNP and SNP-by-smoking interaction identifies novel loci for pulmonary function. PLoS Genetics. 2012;8(12): e1003098. doi:10.1371/journal.pgen.1003098.

25. Thorgeirsson TE, Gudbjartsson DF, Surakka I, Vink JM, Amin N, Geller F, et al. Sequence variants at CHRNB3-CHRNA6 and CYP2A6 affect smoking behavior. Nature Genetics. 2010;42(5):448-53. doi:10.1038/ng.573.

26. Liu JZ, Tozzi F, Waterworth DM, Pillai SG, Muglia P, Middleton L, et al. Meta-analysis and imputation refines the association of 15q25 with smoking quantity. Nature Genetics. 2010;42(5):436-40. doi:10.1038/ng.572.

27. Tobacco GC. Genome-wide meta-analyses identify multiple loci associated with smoking behavior. Nature Genetics. 2010;42(5):441-7. doi:10.1038/ng.571.

28. Tang W, Kowgier M, Loth DW, Soler Artigas M, Joubert BR, Hodge E, et al. Large-scale genome-wide association studies and meta-analyses of longitudinal change in adult lung function. PloS One. 2014;9(7):e100776. doi:10.1371/journal.pone.0100776.

29. Lee JH, Cho MH, Hersh CP, McDonald ML, Crapo JD, Bakke PS, et al. Genetic susceptibility for chronic bronchitis in chronic obstructive pulmonary disease. Respiratory Research. 2014;15(1):113. doi:10.1186/s12931-014-0113-2.

30. Pillai SG, Kong X, Edwards LD, Cho MH, Anderson WH, Coxson HO, et al. Loci identified by genome-wide association studies influence different disease-related phenotypes in chronic obstructive pulmonary disease. American Journal of Respiratory and Critical Care Medicine. 2010;182(12): 1498-505. doi:10.1164/rccm.201002-01510C

31. Cho MH, Boutaoui N, Klanderman BJ, Sylvia JS, Ziniti JP, Hersh CP, et al. Variants in FAM13A are associated with chronic obstructive pulmonary disease. Nature Genetics. 2010:42(3):200-2. doi:10.1038/ng.535.

32. Cho MH, Castaldi PJ, Wan ES, Siedlinski M, Hersh CP, Demeo DL, et al. A genome-wide association study of COPD identifies a susceptibility locus on chromosome 19q13. Human Molecular Genetics. 2012;21(4):947-57. doi:10.1093/hmg/ddr524.

33. Kim WJ, Lim MN, Hong Y, Silverman EK, Lee JH, Jung BH, et al. Association of lung function genes with chronic obstructive pulmonary disease. Lung. 2014;192(4):473-80. doi:10.1007/s00408-014-9579-4.

34. Cho MH, McDonald ML, Zhou X, Mattheisen M, Castaldi PJ, Hersh CP, et al. Risk loci for chronic obstructive pulmonary disease: a genome-wide association study and meta-analysis. The Lancet Respiratory Medicine. 2014; 2(3):214-25. doi:10.1016/S2213-2600(14)70002-5.

35. Wilk JB, Shrine NR, Loehr LR, Zhao JH, Manichaikul A, Lopez LM, et al. Genome-wide association studies identify CHRNA5/3 and HTR4 in the development of airflow obstruction. American Journal of Respiratory and Critical Care Medicine. 2012;186(7):622-32. doi:10.1164/rccm.201202-0366OC.

36. Soler Artigas M, Wain LV, Repapi E, Obeidat M, Sayers I, Burton PR, et al. Effect of five genetic variants associated with lung function on the risk of chronic obstructive lung disease, and their joint effects on lung function. American Journal of Respiratory and Critical Care Medicine. 2011;184(7):786-95. doi:10.1164/rccm.201102-01920C.

37. Brehm JM, Hagiwara K, Tesfaigzi Y, Bruse S, Mariani TJ, Bhattacharya S, et al. Identification of FGF7 as a novel susceptibility locus for chronic obstructive pulmonary disease. Thorax. 2011;66(12):1085-90. doi:10.1136/thoraxinl-2011-200017.

38. Pillai SG, Ge D, Zhu G, Kong X, Shianna KV, Need AC, et al. A genome-wide association study in chronic obstructive pulmonary disease (COPD): identification of two major susceptibility loci. PLoS Genetics. 2009;5(3): e1000421. doi:10.1371/journal.pgen.1000421.

39. Herriges M, Morrisey EE. Lung development: orchestrating the generation and regeneration of a complex organ. Development. 2014;141(3):502-13. doi:10.1242/dev.098186.

40. Collins SA, Lucas JS, Inskip HM, Godfrey KM, Roberts G, Holloway JW, et al, HHIP, HDAC4, NCR3 and RARB polymorphisms affect fetal, childhood and adult lung function. The European Respiratory Journal. 2013;41(3):756-7. doi: 10.1183/09031936.00171712.

41. Warburton D, Bellusci S, De Langhe S, Del Moral PM, Fleury V, Mailleux A, et al. Molecular mechanisms of early lung specification and branching morphogenesis. Pediatric Research. 2005;57(5 Pt 2):26R-37R. doi:10.1203/01.PDR.0000159570.01327.ED
42. Whitsett JA, Wert SE, Trapnell BC. Genetic disorders influencing lung formation and function at birth. Human molecular genetics. 2004;13 Spec No 2:R207-15. doi:10.1093/hmg/ddh252.

43. Morrisey EE, Hogan BL. Preparing for the first breath: genetic and cellular mechanisms in lung development. Developmental Cell. 2010;18(1):8-23. doi: 10.1016/j.devcel.2009.12.010.

44. Rockich BE, Hrycaj SM, Shih HP, Nagy MS, Ferguson MA, Kopp JL, et al. Sox9 plays multiple roles in the lung epithelium during branching morphogenesis. Proceedings of the National Academy of Sciences of the United States of America. 2013;110(47):E4456-64. doi:10.1073/pnas.1311847110.

45. Chang DR, Martinez Alanis D, Miller RK, Ji H, Akiyama H, McCrea PD, et al. Lung epithelial branching program antagonizes alveolar differentiation. Proceedings of the National Academy of Sciences of the United States of America. 2013;110(45):18042-51. doi:10.1073/pnas.1311760110.

46. Warburton D, Bellusci S, Del Moral PM, Kaartinen V, Lee M, Tefft D, et al. Growth factor signaling in lung morphogenetic centers: automaticity, stereotypy and symmetry. Respiratory Research. 2003:4:5. doi:10.1186/1465-9921-4-5.

47. Kerkhof M, Boezen HM, Granell R, Wijga AH, Brunekreef B, Smit HA, et al. Transient early wheeze and lung function in early childhood associated with chronic obstructive pulmonary disease genes. The Journal of allergy and clinical immunology. 2014;133(1):68-76 e1-4. doi:10.1016/j.jaci.2013.06.004.

48. Greenlee K, Werb Z, Kheradmand F. Matrix metalloproteinases in lung: multiple, multifarious, and multifaceted. Physiological Reviews. 2007;87(1): 69-98. doi:10.1152/physrev.00022.2006.

49. Hautamaki RD, Kobayashi DK, Senior RM, Shapiro SD. Requirement for macrophage elastase for cigarette smoke-induced emphysema in mice. Science. 1997;277(5334):2002-4.

50. Hodge E, Nelson CP, Miller S, Billington CK, Stewart CE, Swan C, et al. HTR4 gene structure and altered expression in the developing lung. Respiratory Research. 2013;14:77. doi:10.1186/1465-9921-14-77.

51. Lebeche D, Malpel S, Cardoso WV. Fibroblast growth factor interactions in the developing lung. Mechanisms of Development. 1999;86(1-2):125-36.

52. Deimling J, Thompson K, Tseu I, Wang J, Keijzer R, Tanswell AK, et al. Mesenchymal maintenance of distal epithelial cell phenotype during late fetal lung development. American Journal of Physiology Lung Cellular and Molecular Physiology. 2007;292(3):L725-41. doi:10.1152/ajplung.00221.2006.

53. Shannon JM, Gebb SA, Nielsen LD. Induction of alveolar type II cell differentiation in embryonic tracheal epithelium in mesenchyme-free culture. Development. 1999;126(8):1675-88.

54. Jo A, Denduluri S, Zhang B, Wang Z, Yin L, Yan Z, et al. The versatile functions of Sox9 in development, stem cells, and human diseases. Genes \& Diseases. 2014;1 (2):149-61. doi:10.1016/j.gendis.2014.09.004.

55. Sharma S, Tantisira K, Carey V, Murphy AJ, Lasky-Su J, Celedon JC, et al. A role for Wnt signaling genes in the pathogenesis of impaired lung function in asthma. American Journal of Respiratory and Critical Care Medicine. 2010; 181(4):328-36. doi:10.1164/rccm.200907-10090C.

56. Rock JR, Futtner CR, Harfe BD. The transmembrane protein TMEM16A is required for normal development of the murine trachea. Developmental Biology. 2008:321(1):141-9. doi:10.1016/.ydbio.2008.06.009.

57. Mariani TJ, Reed JJ, Shapiro SD. Expression profiling of the developing mouse lung: insights into the establishment of the extracellular matrix. American Journal of Respiratory Cell and Molecular Biology. 2002;26(5):541-8. doi:10.1165/ajrcmb.26.5.2001-00080c

58. Naxerova K, Bult CJ, Peaston A, Fancher K, Knowles BB, Kasif S, et al. Analysis of gene expression in a developmental context emphasizes distinct biological leitmotifs in human cancers. Genome Biology. 2008;9(7):R108. doi: 10.1186/gb-2008-9-7-r108.

59. Dong J, Jiang G, Asmann YW, Tomaszek S, Jen J, Kislinger T, et al. MicroRNA networks in mouse lung organogenesis. PloS One. 2010;5(5):e10854. doi:10.1371/journal.pone.0010854

60. Liu J, Tseu I, Wang J, Tanswell K, Post M. Transforming growth factor beta2, but not beta 1 and beta3, is critical for early rat lung branching. Developmental Dynamics. 2000;217(4):343-60. doi:10.1002/(SICI)1097-0177(200004)217:4<343: AID-DVDY2>3.0.CO;2-F.

61. Tantucci C, Modina D. Lung function decline in COPD. Int J Chron Obstruct Pulmon Dis. 2012;7:95-9. doi:10.2147/COPD.S27480.

62. Tashkin DP. Variations in FEV(1) decline over time in chronic obstructive pulmonary disease and its implications. Curr Opin Pulm Med. 2013;19(2): 116-24. doi:10.1097/MCP.0b013e32835d8ea4. 
63. Vestbo J, Edwards LD, Scanlon PD, Yates JC, Agusti A, Bakke P, et al, Changes in forced expiratory volume in 1 second over time in COPD. N Engl J Med. 2011;365(13):1184-92. doi:10.1056/NEJMoa1105482.

64. Lange P, Celli B, Agusti A, Boje Jensen G, Divo M, Faner R, et al. LungFunction Trajectories Leading to Chronic Obstructive Pulmonary Disease. N Engl J Med. 2015;373(2):111-22. doi:10.1056/NEJMoa1411532.

65. Sears MR, Greene JM, Willan AR, Wiecek EM, Taylor DR, Flannery EM, et al. A longitudinal, population-based, cohort study of childhood asthma followed to adulthood. N Engl J Med. 2003;349(15):1414-22. doi:10.1056/ NEJMoa022363.

66. Stern DA, Morgan WJ, Wright AL, Guerra S, Martinez FD. Poor airway function in early infancy and lung function by age 22 years: a non-selective longitudinal cohort study. Lancet. 2007;370(9589):758-64. doi:10.1016/ S0140-6736(07)61379-8.

67. Bisgaard H, Jensen SM, Bonnelykke K. Interaction between asthma and lung function growth in early life. American Journal of Respiratory and Critical Care Medicine. 2012;185(11):1183-9. doi:10.1164/rccm.201110-1922OC.

68. Tai A, Tran H, Roberts M, Clarke N, Wilson J, Robertson CF. The association between childhood asthma and adult chronic obstructive pulmonary disease. Thorax. 2014;69(9):805-10. doi:10.1136/thoraxjnl-2013-204815.

69. de Marco R, Accordini S, Cerveri I, Corsico A, Sunyer J, Neukirch F, et al. An international survey of chronic obstructive pulmonary disease in young adults according to GOLD stages. Thorax. 2004;59(2):120-5.

70. de Marco R, Accordini S, Cerveri I, Corsico A, Anto JM, Kunzli N, et al. Incidence of chronic obstructive pulmonary disease in a cohort of young adults according to the presence of chronic cough and phlegm. American Journal of Respiratory and Critical Care Medicine. 2007;175(1):32-9. doi:10.1164/rccm.200603-3810C.

71. Raby BA. On your marks, get set, go! American Journal of Respiratory and Critical Care Medicine. 2012;185(9):904-6. doi:10.1164/rccm.201202-0318ED

72. Hylkema MN, Blacquiere MJ. Intrauterine effects of maternal smoking on sensitization, asthma, and chronic obstructive pulmonary disease. Proceedings of the American Thoracic Society. 2009;6(8):660-2. doi:10.1513/pats.200907-065DP.

73. Pattenden S, Antova T, Neuberger M, Nikiforov B, De Sario M, Grize L, et al. Parental smoking and children's respiratory health: independent effects of prenatal and postnatal exposure. Tobacco Control. 2006;15(4):294-301. doi:10.1136/tc.2005.015065.

74. Moshammer H, Hoek G, Luttmann-Gibson H, Neuberger MA, Antova T, Gehring $U$, et al. Parental smoking and lung function in children: an international study. American Journal of Respiratory and Critical Care Medicine. 2006;173(11):1255-63. doi:10.1164/rccm.200510-15520C.

75. Upton MN, Smith GD, McConnachie A, Hart CL, Watt GC. Maternal and personal cigarette smoking synergize to increase airflow limitation in adults. American Journal of Respiratory and Critical Care Medicine. 2004;169(4):479-87. doi:10.1164/rccm.200211-13570C.

76. Bruin JE, Kellenberger LD, Gerstein HC, Morrison KM, Holloway AC. Fetal and neonatal nicotine exposure and postnatal glucose homeostasis: identifying critical windows of exposure. The Journal of Endocrinology. 2007;194(1): 171-8. doi:10.1677/JOE-07-0050.

77. Maritz GS, Harding R. Life-long programming implications of exposure to tobacco smoking and nicotine before and soon after birth: evidence for altered lung development. International Journal of Environmental Research and Public Health. 2011;8(3):875-98. doi:10.3390/ijerph8030875.

78. Maritz GS. Perinatal exposure to nicotine and implications for subsequent obstructive lung disease. Paediatric Respiratory Reviews. 2013;14(1):3-8. doi:10.1016/j.prrv.2012.03.006.

79. Petre MA, Petrik J, Ellis R, Inman MD, Holloway AC, Labiris NR. Fetal and neonatal exposure to nicotine disrupts postnatal lung development in rats: role of VEGF and its receptors. International Journal of Toxicology. 2011;30(2): 244-52. doi:10.1177/1091581810395332.

80. Sandberg KL, Pinkerton KE, Poole SD, Minton PA, Sundell HW. Fetal nicotine exposure increases airway responsiveness and alters airway wall composition in young lambs. Respiratory Physiology \& Neurobiology. 2011;176(1-2):57-67. doi:10.1016/j.resp.2010.12.015.

81. Wongtrakool C, Wang N, Hyde DM, Roman J, Spindel ER. Prenatal nicotine exposure alters lung function and airway geometry through alpha7 nicotinic receptors. American Journal of Respiratory Cell and Molecular Biology. 2012; 46(5):695-702. doi:10.1165/rcmb.2011-00280C.

82. (US) Department of Health and Human Services, Centers for Disease Control and Prevention, Office on Smoking and Health. Women and Smoking: A Report of the Surgeon General. Atlanta (GA); 2001.
83. Jaddoe WW, Verburg BO, de Ridder MA, Hofman A, Mackenbach JP, Moll HA, et al. Maternal smoking and fetal growth characteristics in different periods of pregnancy: the generation R study. American Journal of Epidemiology. 2007;165(10):1207-15. doi:10.1093/aje/kwm014.

84. Goodwin RD, Keyes K, Simuro N. Mental disorders and nicotine dependence among pregnant women in the United States. Obstetrics and Gynecology. 2007;109(4):875-83. doi:10.1097/01.AOG.0000255979.62280.e6.

85. Andres RL, Day MC. Perinatal complications associated with maternal tobacco use. Seminars in Neonatology. 2000;5(3):231-41. doi:10.1053/siny. 2000.0025 .

86. Bergmann KE, Bergmann RL, Von Kries R, Bohm O, Richter R, Dudenhausen JW, et al. Early determinants of childhood overweight and adiposity in a birth cohort study: role of breast-feeding. International Journal of Obesity and Related Metabolic Disorders. 2003;27(2):162-72. doi:10.1038/sj.ijo.802200.

87. Team LS. Statistics on Women's Smoking Status at Time of Delivery. England: Health and Social Care Information Centre; 2014.

88. Blacquiere MJ, Timens W, Melgert BN, Geerlings M, Postma DS, Hylkema MN. Maternal smoking during pregnancy induces airway remodelling in mice offspring. The European Respiratory Journal. 2009;33(5):1133-40. doi:10.1183/09031936.00129608.

89. Sekhon HS, Jia Y, Raab R, Kuryatov A, Pankow JF, Whitsett JA, et al. Prenatal nicotine increases pulmonary alpha7 nicotinic receptor expression and alters fetal lung development in monkeys. The Journal of Clinical Investigation. 1999;103(5):637-47. doi:10.1172/JCI5232.

90. Breton CV, Vora H, Salam MT, Islam T, Wenten M, Gauderman WJ, et al. Variation in the GST mu locus and tobacco smoke exposure as determinants of childhood lung function. American Journal of Respiratory and Critical Care Medicine. 2009;179(7):601-7. doi:10.1164/rccm.200809-13840C.

91. Bruin JE, Gerstein HC, Holloway AC. Long-term consequences of fetal and neonatal nicotine exposure: a critical review. Toxicol Sci. 2010;116(2):364-74. doi:10.1093/toxsci/kfq103

92. Ginzel KH, Maritz GS, Marks DF, Neuberger M, Pauly JR, Polito JR, et al. Critical review: nicotine for the fetus, the infant and the adolescent? J Health Psychol. 2007;12(2):215-24. doi:10.1177/1359105307074240.

93. Ward LD, Kellis M. Interpreting noncoding genetic variation in complex traits and human disease. Nature Biotechnology. 2012;30(11):1095-106. doi:10.1038/nbt.2422

94. Ritchie GR, Dunham I, Zeggini E, Flicek P. Functional annotation of noncoding sequence variants. Nature Methods. 2014;11(3):294-6. doi:10.1038/nmeth.2832.

95. Coultas DB, Hanis CL, Howard CA, Skipper BJ, Samet JM. Heritability of ventilatory function in smoking and nonsmoking New Mexico Hispanics. The American Review of Respiratory Disease. 1991;144(4):770-5. doi:10.1164/ajrccm/144.4.770.

96. Castaldi PJ, Cho MH, Litonjua AA, Bakke P, Gulsvik A, Lomas DA, et al. The association of genome-wide significant spirometric loci with chronic obstructive pulmonary disease susceptibility. American Journal of Respiratory Cell and Molecular Biology. 2011;45(6):1147-53. doi:10.1165/rcmb.2011-00550C.

97. Konermann S, Brigham MD, Trevino AE, Joung J, Abudayyeh OO, Barcena C, et al. Genome-scale transcriptional activation by an engineered CRISPR-Cas 9 complex. Nature. 2015;517(7536):583-8. doi:10.1038/nature14136.

98. Jackson AL, Bartz SR, Schelter J, Kobayashi SV, Burchard J, Mao M, et al. Expression profiling reveals off-target gene regulation by RNAi. Nature Biotechnology. 2003;21(6):635-7. doi:10.1038/nbt831.

99. Hsu PD, Lander ES, Zhang F. Development and applications of CRISPR-Cas9 for genome engineering. Cell. 2014;157(6):1262-78. doi:10.1016/j.cell.2014.05.010.

100. Shendure J, Ji H. Next-generation DNA sequencing. Nature Biotechnology. 2008;26(10):1135-45. doi:10.1038/nbt1486.

101. Kos CH. Cre/loxP system for generating tissue-specific knockout mouse models. Nutrition Reviews. 2004;62(6 Pt 1):243-6.

102. Kajekar R. Environmental factors and developmental outcomes in the lung. Pharmacology \& Therapeutics. 2007;114(2):129-45. doi:10.1016/j.pharmthera. 2007.01.011.

103. Van Durme YM, Eijgelsheim M, Joos GF, Hofman A, Uitterlinden AG, Brusselle GG, et al. Hedgehog-interacting protein is a COPD susceptibility gene: the Rotterdam Study. The European Respiratory Journal. 2010;36(1): 89-95. doi:10.1183/09031936.00129509.

104. Hansel NN, Ruczinski I, Rafaels N, Sin DD, Daley D, Malinina A, et al Genome-wide study identifies two loci associated with lung function decline in mild to moderate COPD. Human Genetics. 2013;132(1):79-90. doi:10.1007/s00439-012-1219-6. 
105. Kong X, Cho MH, Anderson W, Coxson HO, Muller N, Washko G, et al. Genome-wide association study identifies BICD1 as a susceptibility gene for emphysema. American Journal of Respiratory and Critical Care Medicine. 2011;183(1):43-9. doi:10.1164/rccm.201004-05410C.

106. Cardoso WV, Lu J. Regulation of early lung morphogenesis: questions, facts and controversies. Development. 2006;133(9):1611-24. doi:10.1242/dev.02310.

107. Warburton D, El-Hashash A, Carraro G, Tiozzo C, Sala F, Rogers O, et al. Lung organogenesis. Current topics in Developmental Biology. 2010;90:73-158. doi:10.1016/S0070-2153(10)90003-3.

108. Warburton D, Schwarz M, Tefft D, Flores-Delgado G, Anderson KD, Cardoso $\mathrm{W}$. The molecular basis of lung morphogenesis. Mechanisms of Development. 2000;92(1):55-81.

109. Warburton D, Bellusci $S$. The molecular genetics of lung morphogenesis and injury repair. Paediatric Respiratory Reviews. 2004;5 Suppl A:S283-7.

110. Wallingford JB. Planar cell polarity and the developmental control of cell behavior in vertebrate embryos. Annual Review of Cell and Developmental Biology. 2012;28:627-53. doi:10.1146/annurev-cellbio-092910-154208.

111. Pongracz JE, Stockley RA. Wnt signalling in lung development and diseases. Respiratory Research. 2006;7:15. doi:10.1186/1465-9921-7-15.

112. Desai TJ, Chen F, Lu J, Qian J, Niederreither K, Dolle P, et al. Distinct roles for retinoic acid receptors alpha and beta in early lung morphogenesis. Developmental Biology. 2006;291(1):12-24. doi:10.1016/j.ydbio.2005.10.045.

113. Rhinn M, Dolle P. Retinoic acid signalling during development. Development. 2012;139(5):843-58. doi:10.1242/dev.065938.

114. Xu K, Moghal N, Egan SE. Notch signaling in lung development and disease. Advances in Experimental Medicine and Biology. 2012;727:89-98. doi:10. 1007/978-1-4614-0899-4_7.

115. Yates LL, Schnatwinkel C, Murdoch JN, Bogani D, Formstone CJ, Townsend $\mathrm{S}$, et al. The PCP genes Celsr1 and Vangl2 are required for normal lung branching morphogenesis. Human Molecular Genetics. 2010;19(11):2251-67. doi:10.1093/hmg/ddq104.

116. Yates LL, Schnatwinkel C, Hazelwood L, Chessum L, Paudyal A, Hilton H, et al. Scribble is required for normal epithelial cell-cell contacts and lumen morphogenesis in the mammalian lung. Developmental Biology. 2013;373(2): 267-80. doi:10.1016/j.ydbio.2012.11.012.

117. Bellusci S, Furuta Y, Rush MG, Henderson R, Winnier G, Hogan BL. Involvement of Sonic hedgehog (Shh) in mouse embryonic lung growth and morphogenesis. Development. 1997;124(1):53-63.

118. Dean CH, Miller LA, Smith AN, Dufort D, Lang RA, Niswander LA. Canonical Wnt signaling negatively regulates branching morphogenesis of the lung and lacrimal gland. Developmental Biology. 2005;286(1):270-86. do::10.1016/j.ydbio.2005.07.034.

119. Wang XD, Leow CC, Zha J, Tang Z, Modrusan Z, Radtke F, et al. Notch signaling is required for normal prostatic epithelial cell proliferation and differentiation. Developmental Biology. 2006;290(1):66-80. doi:10.1016/j. ydbio.2005.11.009

120. Chen F, Desai TJ, Qian J, Niederreither K, Lu J, Cardoso WV. Inhibition of Tgf beta signaling by endogenous retinoic acid is essential for primary lung bud induction. Development. 2007;134(16):2969-79. doi:10.1242/dev.006221.

121. Koopman P. Organogenesis in development. Preface. Current topics in developmental biology. 2010;90:xiii-xiv. doi:10.1016/S0070-2153(10)90016-1

122. Bancalari E. The Newborn Lung: Neonatology Questions and Controversies. Elsevier Health Sciences; 2012, 2nd edition, Section A.

\section{Submit your next manuscript to BioMed Central and take full advantage of:}

- Convenient online submission

- Thorough peer review

- No space constraints or color figure charges

- Immediate publication on acceptance

- Inclusion in PubMed, CAS, Scopus and Google Scholar

- Research which is freely available for redistribution 